\title{
AÇÃO DO ENFERMEIRO FRENTE ÀS NOVAS DEMANDAS DO HOMEM
}

Isabel Amélia Costa Mendes ${ }^{1}$

\begin{abstract}
A história da condição humana ilustra a busca da humanidade para se libertar do trabalho que não seja digno de um viver verdadeiramente humano.

$\mathrm{Na}$ assistência à saúde estamos atravessando uma crise em decorrência da inadequada utilização de conceitos provenientes da visão de mundo mecanicista. Inadequada porque tais conceitos ainda têm sido aplicados ao contexto de saúde que não tem mais suportado este paradigma.

À enfermagem estão se revelando, cada vez mais, as contenções, limitações e insuficiências impostas por esse modelo.

É lugar comum dizer que, nesse sentido, a vida do trabalhador se torna desumana e que também desumano acaba sendo seu processo de trabalho.

Felizmente a crise se torna intensa, e agudece em função de rejeição ao modelo vigente. Emerge então uma nova visão, com outros valores. Nesta transição passamos a considerar a necessidade de uma transformação cultural em nossas instituições de saúde. Que esta transformação se paute na solidariedade através do diálogo e da ação!

Aliás, é com palavras e atos que o enfermeiro se introduz no mundo humano. A sua introdução neste cenário se dá pelo estímulo que a presença do outro desperta, pelo anseio da companhia e da proximidade, enfim, pelo desejo de ele próprio - o enfermeiro - ser e agir em consonância com sua essência humana. Desta maneira, a ação humanizadora do enfermeiro se desvela pelo diálogo, pelas palavras, mostrando quem é e a que veio, ao mesmo tempo que deseja conhecer o outro, suas singularidades, para com ele estabelecer uma convivência autêntica. É uma ação que provoca reação do outro, no sentido de resposta que compartilha, ou de resposta que contém diversidade e assim provoca nova ação.

É compreensível para o enfermeiro que o cliente, ou o seu colaborador de enfermagem, sejam sujeitos com potencial de poder em relação à reciprocidade das ações.

É assim que interpretamos a nova visão de mundo, o novo paradigma emergente. Aqui a condição humana do trabalhador de enfermagem, bem como a condição humana do cliente, estarão sendo respeitadas através do empenho do enfermeiro em favor de um trabalho digno, ou melhor, de ações e discursos compatíveis com a natureza e as aspirações humanas frente as suas necessidades mais fundamentais. Nessa perspectiva, a utilidade decorrente de seu trabalho é uma questão meramente conseqüente.

Assim sendo, o enfermeiro estará exercendo a enfermagem pelo seu lado arte, conciliando a técnica - a dimensão instrumental - com o humanismo.

A ação de cuidar, alicerçada na arte, é traduzida pela sensibilidade das pessoas envolvidas que ultrapassa e vai muito além dos requisitos exigidos pura e simplesmente pela razão.

Assim visualizamos e acreditamos no novo pautar do comportamento do enfermeiro, o qual contribuirá para a transformação cultural em nossas instituições prestadoras de serviços à saúde.
\end{abstract}

\footnotetext{
${ }^{1}$ Vice-Presidenta da Comissão de Editoração da Revista Latino-Americana de Enfermagem, Professor Titular da Escola de Enfermagem de Ribeirão Preto da Universidade de São Paulo, Centro Colaborador da OMS para o desenvolvimento da pesquisa em enfermagem, e-mail: iamendes@eerp.usp.br
} 


\section{NURSES' ACTIONS IN FACE OF MAN'S NEW NEEDS}

Isabel Amélia Costa Mendes ${ }^{1}$

The history of human conditions illustrates man's attempts to become free from work that is not worthy of truly human living.

Health care is presently facing a crisis due to the inadequate use of concepts arising from a mechanistic view of the world. It is inadequate because such concepts are still being applied to a health care context that no longer supports such paradigm.

The containment, limitations and insuficiency imposed by such model are being more and more frequently revealed to nursing. In this sense, it is needless to say that workers' lives become inhuman and eventually so does their work process.

Fortunately, the crisis has become intense and acute due to the rejection to the present model. A new view, with different values, then emerges. In this transition, we begin to consider the need for a cultural change in our health care institutions, which must be based on solidarity through dialogue and action!

In fact, it is through words and acts that nurses introduce themselves in the human world. Their introduction in this scenario takes place by means of the stimulation that the other's presence awakens, by longing for company and proximity, that is, through the desire that he himself - the nurse - be and act in consonance with his human essence. In this way, the nurse's humanizing action is unveiled through dialogue and words by showing who he is and why he is there at the same time that he wishes to know the other and his singularities so that they can share an authentic experience. It is action that causes the other to react with a response which is shared or contains diversity, thus causing a new action

The fact that his client and his nursing collaborator are subjects who have a potential power in relation to action reciprocity is understandable to the nurse.

This is how we interpret the new view of the world, the new emerging paradigm. Here, the nursing worker's human condition as well as the client's are being respected through the nurse's efforts in favor of a worthy work, that is, through actions and discourses that are compatible with the human nature and aspirations in face of his most fundamental needs. In this perspective, the utility arising from his work is merely a consequent question.

Therefore, nurses are performing the nursing practice through its artistic aspect by combining technique - the instrumental dimension - with humanism.

The action of art-based caring is translated by the sensitivity of the person involved in it, which reaches far beyond the requirements that are simply established by reason.

This is how we view and believe in the new basis of the nurse's behavior, which will contribute to the cultural transformation in our health care institutions.

\footnotetext{
${ }^{1}$ Vice-President of the Editorial Board of Revista Latino-Americana de Enfermagem and Full Professor in the Nursing at the University of São Paulo at Ribeirão Preto College of Nursing, WHO Collaborating Center for nursing research development, e-mail: iamendes@eerp.usp.br
} 


\title{
ACCIÓN DEL ENFERMERO FRENTE A LAS NUEVAS DEMANDAS DEL HOMBRE
}

Isabel Amélia Costa Mendes ${ }^{1}$

\begin{abstract}
La historia de la condición humana ilustra la búsqueda de la humanidad para libertarse del trabajo que no sea digno de una vida verdaderamente humana.

En la atención a la salud estamos atravesando una crisis debido a la inadecuada utilización de conceptos provenientes de la visión de mundo mecanicista. Inadecuada porque tales conceptos aun continúan siendo aplicados en el contexto de salud, el cual no soporta más este paradigma.

La enfermería se está revelando, cada vez más a las contenciones, limitaciones e insuficiencias impuestas por ese modelo.

Es común decir que, en ese sentido, la vida del trabajador se torna deshumana y que también deshumano acaba siendo su proceso de trabajo.
\end{abstract}

Felizmente, la crisis se vuelve interesante y se agudiza en función del rechazo al modelo vigente. Emerge entonces una nueva visión, con otros valores. En ésta transición pasamos a considerar la necesidad de una transformación cultural en nuestras instituciones de salud. Que ésta transformación se base en la solidaridad a través del dialogo y de la acción.

Es con palabras y actos que el enfermero se introduce en el mundo humano. Su introducción en éste escenario se da por el estimulo que la presencia del otro despierta, por el ansia de la compañia y de la proximidad, en fin, por el propio deseo del enfermero ser y actuar en consonancia con su esencia humana. De ésta manera, la acción humanizadora del enfermero se desvela por el dialogo, las palabras, mostrando quien es y a que vino, al mismo tiempo que desea conocer al otro, sus singularidades, para establecer con el una convivencia autentica. Es una acción que provoca la reacción del otro, en el sentido de respuesta que comparte o de respuesta que contiene diversidad y así provoca una nueva acción.

Es comprensible para el enfermero que el cliente, o su colaborador de enfermería sean sujetos con potencial de poder en relación con la reciprocidad de las acciones.

Es así que interpretamos la nueva visión de mundo, el nuevo paradigma emergente. Aquí la condición humana del trabajador de enfermería, así como también la condición humana del cliente, estarán siendo respetadas a través del empeño del enfermero a favor de un trabajo digno, o mejor, de acciones y discursos compatibles con la naturaleza y las aspiraciones humanas frente a sus necesidades más fundamentales. En esa perspectiva, la utilidad derivada de su trabajo es una cuestión meramente consecuente.

Siendo así, el enfermero estará ejerciendo la enfermería por el lado del arte, conciliando la técnica - la dimensión instrumental - con el humanismo.

La acción de cuidar, sustentada en el arte, es traducida por la sensibilidad de las personas comprometidas que sobrepasa y va más allá de los requisitos exigidos pura y simplemente por la razón.

Así visualizamos y creemos en una nueva forma de comportamiento del enfermero, la cual contribuirá para la transformación en nuestras instituciones prestadoras de servicios de salud.

\footnotetext{
${ }^{1}$ Vicepresidenta de la Comisión Editorial de la Revista Latinoamericana de Enfermería, Professor Titular de la Escuela de Enfermería de Ribeirão Preto de la Universidad de São Paulo, Centro Colaborador de la OMS para el desarrollo de la investigación en enfermería, e-mail: iamendes@eerp.usp.br
} 
